\title{
Unlearning my communication pedagogy through poetic inquiry
}

\section{Wendy Rawlinson}

\author{
Department of Media, Language and Communication, University of Technology, Durban \\ South Africa \\ wendyrawlinson2@gmail.com \\ https://orcid.org/0000-0003-0980-8113
}

(Received: 15 February 2020; accepted: 15 September 2020)

\begin{abstract}
Feeling disenchanted with my communication pedagogy to undergraduate students at a university of technology, I searched for a means to improve my practices. Poetic inquiry assisted in unveiling how my personal and professional lived experiences had moulded my lecturer self and negatively influenced my communication practices. The reflexive writing of poems created an imaginative space in which embedded values and assumptions could be excavated, and the complexity of my entrenched beliefs made visible. The creative space helped crystallise my thinking and generate fresh insights into my white race and class privilege. New interpretations of how a merging of my personal and professional identities could improve my classroom teaching and learning were evoked through poetic inquiry. Furthermore, as a form of analysis, it served to disrupt ingrained instrumentalist patterns of thinking and acting whilst enabling a more imaginative envisioning of my communication pedagogy.
\end{abstract}

Keywords: white identity, undergraduate students, poetic inquiry

\section{Introduction}

For this article, I drew on the data of my doctoral study (Rawlinson, 2019), which explained how I explored my communication pedagogy in relation to diverse undergraduate students. I attempted to unearth the way in which my apartheid socialisation had influenced my teaching and student learning. Disillusioned with my ineffectual communication teaching and student learning, I searched for a means to explore why, despite the changing sociopolitical context in South African higher education after the democratic election in 1994, my communication pedagogy had remained unchanged. The communication curriculum I taught at a university of technology comprised prepackaged content transmitted in delivery mode, which was convenient for me because it provided control and predictability. But the material and methods did not allow for the different context and altered student body that confronted me- 
and this needed to be interrogated. Self-study methodology offered potential for selfevaluation, for excavating who I was as educator, to improve my practice, and effect social change. I employed an "arts-based self-study method" advocated by Samaras (2011, p. 719) because I wanted to symbolise, represent, construct, and deconstruct my thinking about teaching (Weber \& Mitchell, 2004). Part of deconstructing my pedagogy would be to unlearn how I thought about and enacted my practices in the classroom.

I believed two critical questions would provide a better understanding of how my personal and professional identities interacted in my practices and might shed light on how I could improve. They were formulated as follows: "What personal and professional meanings of self shape my communication lecturer identity?" and "How does my communication lecturer identity mould my practices?" These two questions are set against a backdrop of the injustices of an unfair and destructive Bantu Education system (Christie \& Collins, 1982) that produced students who, despite physical access, frequently were not able to succeed in higher education. In pursuing the questions, I felt a responsibility as educator to explore my personal life history as a means of bringing to life the diverse dimensions of my lived experience.

\section{Data sources and methodology}

\section{My personal history narrative}

Growing up in the 1960s in a white middle-class family in a suburb designated for whites, and where everyone spoke English, was regarded as the norm for me. The segregated system of living where only whites were permitted to live in particular areas was dictated by apartheid policy. Racial classifications based on the grouping of white, Indian, coloured, and black people were employed by the government to separate and oppress people (Clark \& Worger, 2016). My attendance at a whites-only school didn't seem strange to me. Reading was a family ritual that I looked forward to, as were the speech and drama lessons in which I participated. In addition, having a poem chosen for a school magazine, although exciting, was not regarded as unusual. My training at university, as well as my later teaching experience with an all-white student population went largely unquestioned. My access to resources was accepted without question, and my socialisation groomed me for an all-white world where privilege and benefit was unconsciously expected.

My struggles to change from teaching an all-white student body prior to 1994, to a largely black student group of undergraduate students at a university of technology after the democratic election, were reflected in my poor results. I taught the subject, communication, which included communication theory, verbal and non-verbal communication, as well as the writing of English. Teaching methods that revolved around imposing one's personal authority offered minimal student engagement. Many students were from low socioeconomic environments, with seventy percent of those at my institution supported by financial aid from the National Student Financial Aid Scheme (Bhorat \& Pillay, 2017). In addition, inadequate prior schooling, poverty, and lack of resources often prevented optimal learning at university. Research documenting student struggles in South African higher education institutions and 
high dropout rates (Letseka \& Maile, 2008; Mngomezulu \& Ramrathan, 2015), illustrated similar experiences to mine. That research had addressed systemic features of the university but, except for Jawitz (2016), did not excavate the underlying racist ideologies perpetuated by individuals. I reasoned that developing a self-consciousness regarding my personal beliefs and behaviours might be helpful to engage a community of learners and provide a space for a conscientisation of the surrounding power hierarchies.

I was led to examine self-study (Samaras et al., 2004) as a possible methodology to explore my communication pedagogy because it places self at the centre and interrogates what an educator does. As claimed by Pinnegar (1998, p. 33), it is "a methodology for studying professional practice settings" in addition to incorporating a call to action (Pithouse et al., 2009). As well as personal change, it embraces a "social-pedagogical task" (LaBoskey, 2004, p. 830). In inviting a variety of methods (LaBoskey, 2004) such as arts-based methods and memory work that could include metaphor, artefacts, photographs, and poetry, I believed reflexive devices such as these could better reveal my self and my practices.

\section{Poetic inquiry}

Eisner's claim (1991) that meaning is mediated by form propelled me to experiment with poetic form. Poetry as a "kind of expressive writing," whose primary function, according to Percer (2002, p. 9), can act as research, became an option for me to better enhance and understand the process of unveiling my personal and professional lived experience. Prendergast (2009, p. XXI) claimed that "the potential power of poetic inquiry is to do as poetry does, that is to synthesize experience in a direct and affective way." I decided to pursue this option because I believed it would assist in "an evocative portrayal" (ButlerKisber, 2002, p. 232), especially in relation to the communication discipline that I taught. Furman et al. (2007) demonstrated how using different poetic forms in conjunction with traditional data analysis methods could result in data that are emotionally evocative and highly consumable. I was encouraged by Eisner's (1997, p. 9) claim that alternative forms of data representation, including poetry, can "increase attention to complexity, feeling, and new ways of seeing."

The two experimental poetic texts I offer in this article are an "an attempt to reveal the many layers of experience and understanding that become sterilised or otherwise reduced when translated into more traditional texts" (Percer, 2002, p. 9). They helped represent different dimensions of what I was coming to know about my identity as I employed a poetic inquiry lens. In his discussion of poetry as a tool of social educational research, (Willis, 2002) stated that, "poetry is valued as good and useful when it opens up a useful space that is shared between reader and poet," which is what I intended to make available.

In my personal history narrative, I drew on Samaras et al. (2004) whose description of this method incorporated "artistic expression such as drawing, photography and poetry." I followed their suggestion by using photographs, and artefacts to elicit nodal moments in my personal life, growing up as a white girl in apartheid South Africa, as well as journal entries. 
Barone and Eisner (1997, p. 75), maintained that "arts-based research is defined by the presence of aesthetic qualities or design elements that infuse the inquiry and its writing." It can help evoke thoughts and feelings in others and serve to share insights, which I intended to do. A drawback of poetry is that it is not generalisable, but researchers have claimed that "although it is personal it is the goal to transform his or her personal experience into that which is universal" (Furman et. al., 2007, p. 303). Secondly, "poetry is often utilized as a means of inquiry - that is, the process of writing research poems helps the author develop new insights" (Furman et al., 2007, p. 304). Furthermore, attention to the sound of language and form that is required in poetry can contribute to a deeper sensitivity as details of our research experiences are relayed.

Another quality of poetic inquiry aligns with Gunzenhauer's (2008) argument that providing alternative discourses about the meaning and value of the arts is a way of resisting the normalising systems of education, or of challenging traditional understandings of validity (Richardson, 1993). Not wishing to replace traditional forms of prose, poetry presents knowledge in a different form because poetry can affect us bodily so that we experience vicariously the emotions and physical effects of our self -reflexive processes (Richardson, 1994). In expressive poems, the researcher-poet "utilizes their own observations and selfreflection as derived insights to craft works that attempt to metaphorically penetrate the essence of an experience" (Furman, 2004, p. 83). I was further encouraged to employ this method by Cahnmann (2003, p. 34) who claimed that "using elements of poetry in our data collection, analysis and write-up has the potential to make our thinking clearer, fresher and more accessible and to render the richness and complexity of the observed world." I demonstrate in the writing of the poems a "knowing in the making" referred to by Badley (2009, p. 108). The two poems I present in this article helped me to explore an imaginative space that constituted a poetic dialogue with my self. Employment of "artful portrayals" serving as analytic processes (Butler-Kisber, 2002, p. 229) were utilised to ensure both engagement of the researcher-poet in a process of self-reflection and rigour, as well as a means to expose biases (Cresswell, 2007).

\section{Construction of my own trencadis mosaic}

In contemplating my first research question, "What personal and professional meanings of self shape my communication lecturer identity?" I was drawn to a photograph of myself positioned on the trencadis bench in Park Guell, Barcelona. The photograph, taken after a language conference, illustrated a significant lived experience in which I understood how my personal experience was intertwined with my professional practices. The word "trencadis" in Catalan means brittle or mosaic_-also, cracked or broken. Gaudi, a famous architect, devised the decorative technique of placing fragments of tile to form new patterns in situ. This decorative technique could transform an ordinary structure into something extraordinary. Vivid memories of this moment seated on the trencadis bench inspired me to build a trencadis mosaic as a means to extend my thinking on the formation of my personal and professional identities. 
Preparing to construct the mosaic (see photograph, Figure 1), stirred anticipation for insight into new spaces. Although initially tentative, I was spurred on by hooks, who claimed that "without the ability to imagine, people remain stuck, unable to move into a place of power and possibility" (2010, p. 61).

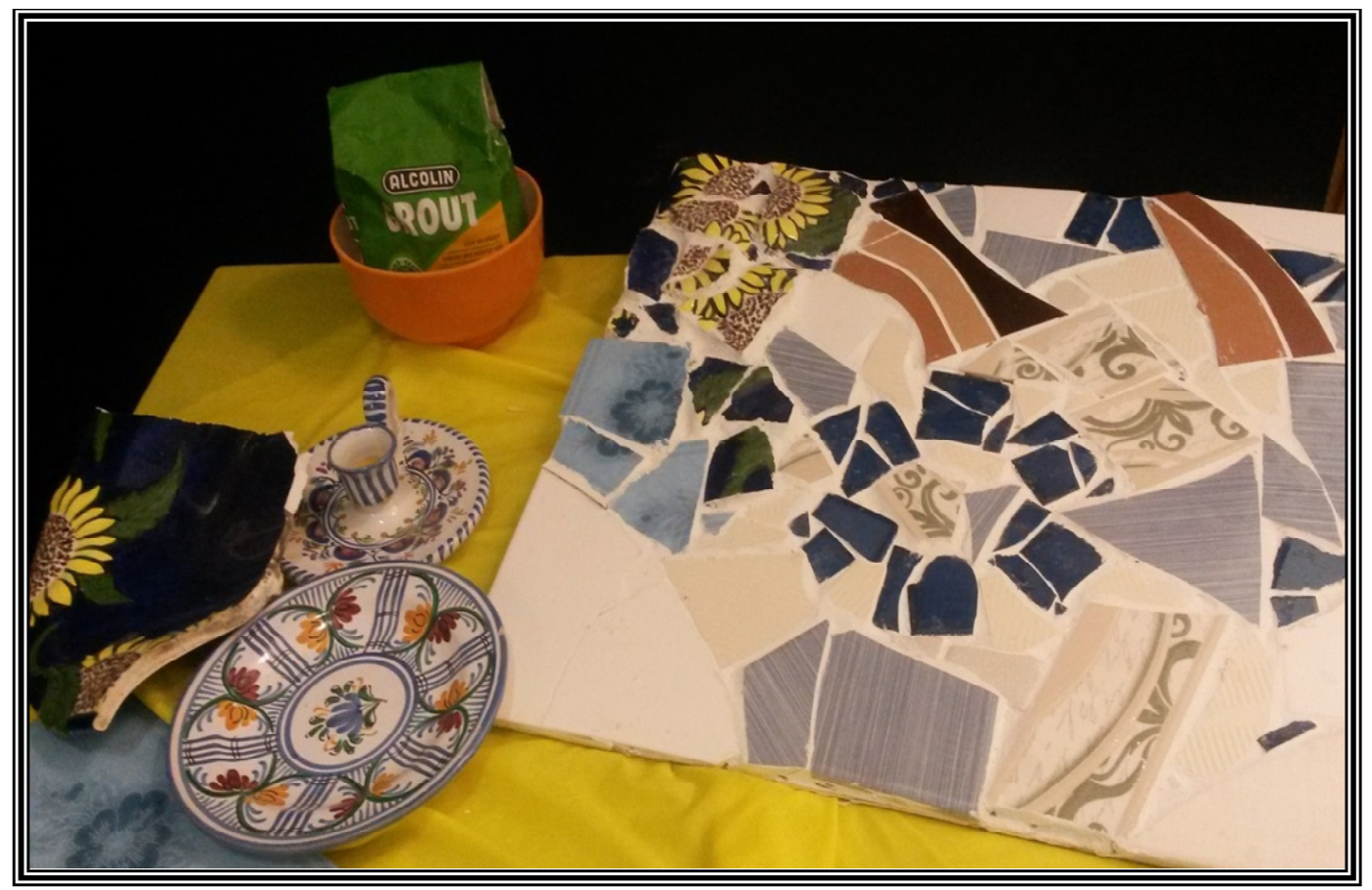

Figure 1: My constructed trencadis mosaic

During construction of the trencadis mosaic, I couldn't help noticing the similarities between my life and the process of constructing a mosaic from broken fragments. The tile shards reflected the social, academic, cultural, and geographic disparities as well as the diverse educational experiences of my life. After completion of the mosaic, I felt compelled to write the poem, "(Re)constructing the Mosaic Text," which juxtaposes my life as communication lecturer with the constructing of the multifarious trencadis mosaic. The construction was birthed out of a desire to give voice to the meaning making and insights that my teacher identity was revealing. It provoked a desire to employ flexibility, spontaneity, and include the aesthetic as reflected in textural forms.

\section{Construction of the poems}

In the writing of my poems, I experimented with words to create rhythm, pauses, and emphasis (Leggo, 2008). Drawing on my personal narrative as data, I attempted to capture the emotions and activities that constituted my identity construction and communication practices. As part of the deconstruction and reconstruction process, words and phrases were rearranged to match my unfolding understanding. By coding the data patterns, tensions and themes were highlighted (Clandinin \& Connelly, 2000), which I then represented in the poems. These crafted poems were a synthesis and interpretation of the observed data. Through the poetic form, serving as a means and an end, I was able to "transfer cognitive and affective knowledge from artist/researcher to reader" (Prendergast, 2004, p. 75). I invited 
critical friends to critique and analyse my poems in progress as I presented them in workshops. Critical collaborative inquiry (Samaras, 2011) in the form of critical friends, and encouraged in self -study, contributed to trustworthiness. The scholarly conversations helped to avoid the pitfalls of navel-gazing, and allowed for diverse interpretations.

In the presence of critical friends, I found that reading the poems aloud aroused emotions that accompanied my experiences at the time. Experiencing poetry's performative and creative activity (Leggo, 2005), illustrated its ability to move listeners, some of whom could relate the embodiment of my difficulties to their educational and personal experiences. The poems encapsulate the physical, emotional, and intellectual struggle of this process as well as the envisioning of my communication lecturer identity. Creation of my trencadis mosaic served to open up my thinking. The process of writing itself became a meditative inquiry space in which to express my emotions and thoughts and to undo my embedded, instrumentalist forms of thinking and enacting pedagogy.

Employment of the original poetry I created aided in crystallising my thinking (Prendergast, 2006) about my identity as communication lecturer, and afforded opportunity to distil the recurring concepts, for example, white privilege, deficit understandings of students, rigid notions of knowledge, and biased beliefs about race, class, and culture. I experienced what Leggo argued about poetry's two-fold ability - that it is not only able to "reveal identity and understanding, but the ways we also engage constantly in constituting and reconstituting our sense of self and identity" (2008, p. 445). The nonlinear format of the free verse poems helped to dissect the layers of meanings that emerged in the process of unlearning my communication pedagogy. The three stanzas of the poem, "(Re)constructing the Mosaic Text," assisted in analysing the process of unlearning the self.

\section{(Re)constructing the Mosaic Text}

Skilfully selecting ceramic segments

Multiple hues reflecting off shiny surfaces recall visions of a distant time and place.

Matching colours and patterns of the past-memories of the untold

Crafting the everyday collage of self

What stories count?

Construction of the trencadis mosaic illuminated the constitutive process of my own life and professional practices and the understanding of myself in a new way (Govinden, 1995). Selecting personal lived experiences to insert in my narrative, and to position them "under the microscope" was as difficult as selecting the tile fragments. The challenging decisions, emotions, and physicality of the process of uncovery and recovery of self demanded more from me than I had anticipated. I relived what Falzon (1998, p. 90) referred to as "having to forsake security and stability and expose ourselves to risk and uncertainty." The mosaicmaking process reflected my experience of feeling alienated, inflexible, and a misfit in the academic landscape. 


\begin{abstract}
Breaking the ceramic bowl against a rock of beliefs
Wincing as splinters pierce my flesh

Lingering pain as I nurse my bleeding assumptions

Placing each piece in situ familiar shapes nudge forward.

Moulded mosaics struggling to adapt to contoured surfaces

Why can't I fit in?
\end{abstract}

I struggled to break the tile into fragments and to then form patterns because of the tile's unpredictable shapes. The procedure reflected the painful process of smashing my entrenched beliefs, and the splintering of deficit discourses to which I had held on. The demand for honesty (Cahnmann, 2003, p. 34) that the poem allowed highlighted my struggle to candidly portray my thoughts and professional experiences. The expressive poetic form offered glimpses of my reduced thinking and understanding that surprised me. The construction process forced confrontation of my beliefs about the nature of an effective lecturer and what constituted my racist perceptions, which West (2009) asserted are difficult to change.

Squeezing the grouting, sealing the cracks, urgently filling the spaces of my lack How can I connect?

Sponging off the excess grout residue

Engaging in an aesthetics-a poetics

Creating a three-dimensional artwork;

Merging my multiple selves

This stanza speaks to the difficulty of being reshaped in order to transform. My discomfort at conforming to institutional curricula and prescriptive methods is highlighted in the struggle to adapt the tile shards to different dimensions and patterns of the mosaic. I recognised my inflexibility to be moulded to an unfamiliar terrain with a majority black student group whose race, class, and language differed from mine. Although confronting my biases was painful, removing the residue of my entitlement brought relief in part, as well as an accompanying understanding that the emotional self could merge with the intellectual self. This enabling space where I could practise my selves as more fluid (Flores \& Day, 2006) spilled over into recognising the less dominant positioning I had adopted with students at times. The space offered opportunity to consider the aesthetic and functional operating together in which a new, connected community could exist (hooks, 2010).

My second research question, "How does my communication lecturer identity mould my practices?" points to ways in which my white middle-class privilege, which gave me access to affordances and resources, prevented me from freely associating with members of other race groups. The rules of the apartheid state which, according to Haarhoff (1998, p. 10), "denied them access to each other's experience," negatively informed my pedagogy by not allowing me to see the benefit of diversity. The entitlement attributed to my race and class afforded me power and the pathologising of my students who sometimes didn't possess similar resources and cultural capital. My conformity to particular educational systems and practices is reflective of my compliance birthed out of gendered, traditional meanings of being a woman in a patriarchal, apartheid society. 
The second poem, "Prying Open Spaces," allowed me to problematise my daily, conservative enactments in the classroom and outlines how I tried to reimagine fresh ways of being and doing teaching. It served as an imaginative inquiry process to rethink my pedagogy, and is evidence of how I employed poetry to analyse and organise sections of my data through a nonlinear means (Furman, 2006; Poindexter, 1998).

It illustrates how I made decisions in relation to codes of behaviour prescribed by institutional structures, the expectations of colleagues, and academic discourses. My own perceptions also steered my behaviour in attempting to become a more effective lecturer. In questioning who I was as technicist communication lecturer in relation to my undergraduate students, I interrogated what my limits were in terms of beliefs and biases, especially related to race. I searched for alternative pathways to open myself up to others, knowing that I alone didn't have the answers. The first two stanzas of the poem, "Prying Open Spaces," express some of the tensions evident in my attempt to become a more ethical and engaged lecturer.

\section{Prying Open Spaces}

Prying open spaces—-venturing into forgotten corners

Rattling settled views on mosaic shards.

Shifting thought-encrusted tiles resistant to prodding fingers;

Tremors, whispers-pretending not to hear

Pushing into occupied spaces.

Stanza one of the poem sheds light on my desire to open up what had remained closed to me in my communication pedagogy, and to reveal how my assumptions and values shaped my actions. "Rattling settled views on mosaic shards" indicates the necessity of rupturing ideas of self as passive woman. "Shifting thought-encrusted shards" relates to my normalised assumptions about my methods of teaching and assessment and my reticence to discard these ideas. "Resistant to prodding fingers" embodies my discomfort at releasing the sedimented behaviours that Foucault (1997) prompted us to move beyond.

The excerpt from my personal narrative presented below, also illustrates my struggle to escape from systems that confined, such as the fixed view of knowledge (Biggs, 1996) I had endorsed. Selecting noncritical course material for the nonverbal module revealed my understanding of knowledge as essentialised, and underlined my perception of students as passive receptors of knowledge (hooks, 1994).

As a communication lecturer transmitting knowledge by direct instruction was the norm for me. I wanted an interactive classroom so I tried to make the lesson lively and interesting, but came to realise that by delivering the fixed content that I believed was appropriate, I was not allowing student contribution. I recognised a tendency to provide my own examples of non-verbal communication that I felt were relevant and appropriate.

In spite of my espoused desire for engagement- "I wanted an interactive classroom"-my controlling attitude, actions, and my fear to share power is revealed. I saw the limitations 
accompanying my subject position as authoritarian lecturer, and "knowledge producer"this position as expert precluded student participation. The "whispers" in the poem refer to niggly doubts that students could understand me, and to their dissatisfaction with the material. "Pretending not to hear" is evidence of my stubborness to acknowledge any part in my students' inability to learn effectively, preferring to blame institutional systems or students themselves. "Pushing into occupied spaces" illustrates the extent to which my aloof personal stance had moulded my reduced academic self.

The second stanza of "Prying Open Spaces" illustrates a recognition of how my familiar, rigid ways of thinking and acting in the classroom had become difficult to dislodge.

Prying open spaces

Playfully pulling at familiar patterns; Peeling away at pretence.

Intrusions into shadowy spaces-avoiding exposure.

Pursuing a path through the clutter of conventions

Seeking exploratory spaces

The stanza also represents my attempt to expose preconceived assumptions. It reveals my desire to disrupt existing behaviours by shifting taken-for-granted discourses (Sachs, 2001) such as use of the term "non-traditional" students, and technicist ways of being and doing that eliminate critical thinking and spontaneous interaction.

"Playfully pulling at familiar patterns" illustrates how I struggled to dismantle embedded practices in an effort to unlearn my disengaged teacher stance. "Peeling away at pretense" shows the way in which I confronted the role of my emotional self in an effort to integrate it more with my professional activities. My "intrusions into shadowy spaces" of race and class were tenuous as I admitted how my engagement with diverse black students was not working in my classroom (Allen, 2007), and that professing I had a student-centred classroom was inaccurate. I grappled to shed my preconceived ideas as to who I was as white, entitled lecturer (Posel, 2001), and who my students were. My uncertainty to venture into unknown areas constituted "shadowy spaces" because they were not prescribed and posed a risk. In "pursuing a path through the clutter of conventions," I grappled to relinquish the conventions and codes associated with whiteness, race, and position (Walker, 2005) to which I was accustomed. My attempt to adopt an ethical stance by trying alternate, engaged ways of practising communication was thwarted as I came up against traditional institutional practices. Despite the rhetoric of transformation in higher education, this was not evident in academic departments (Badat, 2009) or my practices. In "seeking exploratory spaces," I illustrate a preparedness to pursue critical, connected spaces in which conversations of race, class, and social justice issues are invited (hooks, 2010).

\section{Identifying my restrictions}

I now illustrate how the third stanza of "Prying Open Spaces" enabled me to unveil an earlier classroom situation where some of my privileges and preconceived ideas had played out. I was able to recognise "that part of himself [that the individual must determine] as the prime 
material of his moral conduct" (Foucault, 1985, p. 26). Focusing on the main factor that restricts one's thoughts and actions helped to identify how my racist beliefs and biases that were etched into my classroom practices had reinforced racial and class inequities.

Reflection on the situation described below heightened recognition of my endorsement of a positivist communication course and teaching approach, in spite of the difference in student demographics at the university. In order to reassess the rules to which I subscribed, I was compelled to address the flawed securities to which I had adhered. I recognised "the way in which the individual establishes his relation to the rule and recognizes himself as obliged to put it in practice" (Foucault, 1985, p. 27). This critical moment, one that I have written about in more detail (Pillay et al., 2019), happened in my oral communication class where race and class were unintentionally foregrounded. I had recognised the need to connect more closely with students (Jawitz, 2016) because I could understand the gaping divide between who I was as lecturer and my students.

Whilst appointed at a historically black institution in 1993, I conducted a communication oral class in which a student presented a speech on Bantu Education. His passion for the topic was evident as he spoke loudly and emotionally. This excerpt captures a short section of the lesson and is taken from my personal history narrative.

Student: "We blacks didn't deserve an education it seems." The sarcasm in his voice was unmistakable. I could see his rapid breathing as the pitch of his voice rose.

Student: "Less than human! The whites did this—took away our power!" he continued. His anger was palpable.

Me: I wanted to scream out, "It isn't my fault!" I finally blurted out "I can't help being born white!"

His voice was trembling, but I felt as if all eyes in the room were fixed on me.

Me: I cried out "I'm sorry . . I'm sorry for the enforcement of such an evil system!"

I felt as if the temperature in the room rose: as if a giant boiler had been switched on, and I alone was simmering in the suffocating liquid.

In the critical moment described above, my perception of my student was as "nontraditional." His race, class, and experience were representative of my students who were different from me and my previous white students. The situation further reflects my comparison with what I regarded as "the norm." The race incident exposed my failure to address my whiteness prior to this point and exposed my limitations as I questioned my normalised racial identity, and how it was constraining my view of others. However, through confrontation, I recognised an urgency to view other races in relation to their history and began to embrace new ways of allowing diverse students to feel at home (Walker, 2005) in my classroom. 
Initially, the student's utterances about white oppression had disturbed me and I found myself reacting negatively. In assuming the position of 'innocence' (Steyn, 2001), I denied complicity in apartheid oppression. This is illustrated in my statement: "I wanted to scream out; It isn't my fault!" My outburst is a reminder of the "self-proclaiming innocence of white English speaking South Africans" (West, 2009, p. 102). My final words "I can't help being born white!" reveal my disavowing the signs of my limitations that Foucault (1985) advised is essential for care of the self. I was slowly able to identify my complicity in apartheid policies that privileged one group over the other based on one's race because I was sympathetic to inequities. I began to transform my thinking on race and my blindfolded stance (Posel, 2001). By ignoring my emotions and insight, I would have disabled my choice to adopt an ethical stance advocated by Foucault, and encouraged by self-study methodology.

In acknowledging that my actions and feelings were undergirded by racist ideologies, I was thrust into a position to heed the ethical imperative to transform. Critically looking at the self as a site for change was a catalyst in providing the security for which I was yearning (Nussbaum, 1997), which in essence was an assurance that I could fit in. This stance would also serve as a means for me to feel more at home in the undergraduate classroom, and not merely viewed as perpetrator. However, in pondering these new insights I was mindful that self-study methodology requires critique from others, so I called upon a scholarly group from my doctoral cohort, who were trained to provide critique of our research in progress.

Critical friend 1: The researcher is not seeing herself as teacher in this moment but in her personal race identity. Why did you react so irrationally?

Critical friend 2: This student knows he is safe to express his views. . . But it is evident that her liberal person notions get rocked to the core.

Critical friend 3: This situation highlights learning about self in the self-study, where the participant comes from a comfortable environment and moves into alien territory.

Critical friend 1: Don't be so defensive! Stand back!

Awareness of my race and my middle-class values in comparison to those of my students, had affected my teacher identity. The collision of my white interests and expectations and those of my black students resulted in a strained educational environment (Brown, 2004). My subject position of guilty party resulted in a feeling of being targeted (Jansen, 2009). My disquiet at having my role of communication lecturer disrupted by confrontation of my white privilege (Warren \& Fassett, 2014) changed my view of self as a good teacher in the classroom (Jacklin, 2001). As I grappled with the uncertainty of my teacher identity, evidence of a transitioning in the way I thought was reflected in a critical friend's comment: "This situation highlights learning about self in the self-study."

Thus, the third stanza of "Prying Open Spaces" indicates my movement forward in an effort to transition. 
Portrayals of a curious learner; furtive backward glances

Confronting names and voices lurking in the folds of exclusivity

Releasing thoughts from their silent thinking

Moving past the known, propelled to find new places,

Stumbling into a free space

This stanza highlights my eagerness to reimagine my communication practices. The "furtive backward glances" capture the lingering residue of biased assumptions and my reticence to acknowledge where I had failed. "Confronting names and voices" of the deficit discourses in which I had engaged, namely, the terms, "disadvantaged" and "ESL," forced me to acknowledge that these namings and actions were "lurking in folds of exclusivity" because until then, they had remained invisible. My sense of being othered prompted my irrational reaction but, in turn, caused me to enact agency.

I begin to let go of previous persistent thoughts and perceptions thereby "releasing thoughts from their silent thinking" as I chose to engage as a humane communication lecturer. Grappling to unhinge myself from constraining beliefs motivated my desire to be "propelled to find new places." Addressing my entrapment in conservative thinking and practices permitted a "stumbling into a free space" of unconstrained thinking patterns.

Concerning my teacher self, I made way for the possibility of "stumbling into a free space" in both my thinking and in dominating academic structures. By keeping the personal and professional aspects segregated, I had created unnecessary binaries. Privileges I have benefitted from caused me to favour certain classroom practices, structures, and languages above others.

\section{Discussion}

The poetic inquiry process illustrates my attempt to shake off the restrictive technicist practices promoted during apartheid and that lack criticality. Vale and Jacklin (2009, p. 3) referred to "the number of institutional and social developments that have closed off critical thinking in South Africa." Separating my personal from my professional practices prevented an enlivened communication pedagogy where I was able to integrate elements of my respective identities and allow the contribution of students'experiences. However, I was willing "to acknowledge and accept my own vulnerability and limitations" (Straker, 2013, p. 13) in order to move forward. Alternative spaces to rethink race, class, and culture enabled me to reconnect as an embodied lecturer rather than as an educator who fragmented the personal from the professional.

Reassessing my classroom interaction in which race took centre stage and, in an effort to open myself up to others, the commentary from critical friends assisted in the analysis of my reaction. The challenging of my irrational and instinctive response to the student's oral on Bantu Education helped unpack my defensive position and foregrounded my white privilege (Steyn, 2001) so that my racial self and my academic identity aligned (Jenkins, 2008). Although viewed as "knowledgeable educator" by students, I took on the position of novice 
learner of my own race identity and privilege. Given that my identity was constituted through this communication (Fassett \& Warren, 2007), the lines separating my personal and professional identities were erased. I perceived the student's presentation as a subjective encounter exposing my privileged, white woman status (McIntosh, 1990). Accepting my defensiveness and acknowledging my white privilege opened up a space for thinking differently.

\section{Concluding thoughts}

Reflexive poetic inquiry was the tool that assisted in creating an aesthetic space to reimagine my communication pedagogy. Engaging in the meditative and creative process allowed me to connect in a meaningful way with my teaching practices as embodied communication lecturer. Poetic inquiry and dialogue with critical friends offered a means to imagine inclusive teaching spaces in which race and class are welcomed, and uncertainty and vulnerability possible. I resonate with Pithouse-Morgan et al. (2014) who proposed that by taking risks I opened myself to a way of researching that provokes ongoing, complex, polyvocal conversations. The implication for other researchers is that poetic inquiry has the potential to reveal deep layers of one's own lived experience that might provoke or evoke change in them and their practices. Through poetic inquiry, the poems enabled me to evocatively synthesise the complex process of unlearning my inflexible beliefs and practices in order to make way for new forms of integrated thinking and being as I practised my communication pedagogy.

\section{References}

Allen, B. J. (2007). Theorizing communication and race. Communication Monographs, 74(2), 259-264. doi:10.1080/03637750701393055

Badat, S. (2009). Theorising institutional change: Post-1994 South African higher education. Studies in Higher Education, 34(4), 455-467.

Badley, G. (2009). Academic writing: Contested knowledge in the making? Quality Assurance in Education, 14(2), 104-117.

Barone, T., \& Eisner, E. (1997). Arts-Based educational research. Complementary Methods for Research in Education, 2, 75-116.

Bhorat, H., \& Pillay, N. (2017). The National Student Financial Aid Scheme (NSFAS) and the development of the higher education system in South Africa: A description of the demographics and performance of NSFAS beneficiaries. Labour Market Intelligence Partnership. http://www.psetresearchrepository.dhet.gov.za/document/nationalstudent-financial-aid-schem-nsfas-and-development-higher-education-system-south 
Biggs, J. (1996). Assessing learning quality: Reconciling institutional, staff and educational demands. Assessment and Evaluation in Higher Education, 21(1), 5-16. https://doi.org/10.2304/eerj.2014.13.5.584

Brown, E. (2004). The significance of race and social class for self-study and the professional knowledge base of teacher education. In J. J. Loughran, M. Hamilton, V. K. LaBoskey, \& T. L. Russell (Eds.), International handbook of self-study of teaching and teacher education practices (pp. 517-574). Kluwer.

Butler-Kisber, L. (2002). Artful portrayals in qualitative inquiry: The road to found poetry and beyond. The Alberta Journal of Educational Research, 48(3), 229-239.

Cahnmann, M. (2003). The craft, practice, and possibility of poetry in educational research. Educational researcher, 32(3), 29-36.

Christie, P., \& Collins, C. (1982). Bantu education: Apartheid ideology or labour reproduction? Comparative Education, 18(1), 59-75.

Clandinin, D. J., \& Connelly, F. M. (2000). Narrative inquiry: Experience and story in qualitative research. Jossey-Bass.

Clark, N. L., \& Worger, W. H. (2016). South Africa: The rise and fall of apartheid (3rd ed.). Routledge.

Cresswell, J. W. (2007). Qualitative inquiry \& research design: Choosing among five approaches (2nd ed.). SAGE.

Eisner, E. W. (1991). The enlightened eye: Qualitative inquiry and the enhancement of aesthetic experience. Educational Researcher, 22(7), 5-11.

Eisner, E. W. (1997). The promise and perils of alternative forms of data representation. Educational Researcher, 26(6), 4-10.

Falzon, C. (1998). Foucault and social dialogue: Beyond fragmentation. Routledge.

Fassett, D. L., \& Warren, J. T. (2007). Critical communication pedagogy. SAGE.

Flores, M. A., \& Day, C. (2006). Contexts which shape and reshape new teachers' identities: A multi-perspective study. Teaching and Teacher Education, 22(2), 219-232.

Foucault, M. (1985). The history of sexuality: The use of pleasure (R. Hurley, Trans. Vol. 2). Pantheon.

Foucault, M. (1997). Ethics: Subjectivity and truth: The essential works of Foucault 19541984 (R. Hurley, Trans., P. Rabinow, Ed., Vol. 1). The New Press. 
Furman, R. (2004). Using poetry and narrative as qualitative data: Exploring a father's cancer through poetry. Families, Systems, \& Health, 22(2), 162-170.

Furman, R. (2006). Poetic forms and structures in qualitative health research. Qualitative Health Research, 16(4), 560-566.

Furman, R., Langer, C., Davis, C., Gallardo H. P., \& Kulkarni, S. (2007). Expressive research and reflective poetry as qualitative inquiry: a study of adolescent identity. Qualitative Research, 7(3), 301-315.

Govinden, D. B. (1995). Learning myself anew. Alternation, 2(2), 170-183.

Gunzenhauser, M. G. (2008). Care of the self in a context of accountability. The Teachers College Record, 110(10), 2224-2244.

Haarhoff, D. (1998). The writer's voice: A workbook for writers in Africa. Zebra Press

hooks, b. (1994). Teaching to transgress: Education as the practice of freedom. Routledge.

hooks, b. (2010). Teaching critical thinking: Practical wisdom. Routledge.

Jacklin, H. (2001). Teachers, identities and space. SAIDE.

https://www.oerafrica.org/resource/being-teacher-reading-3-teachers-identities-andspace

Jansen, J. (2009). Knowledge in the blood: Confronting race and the apartheid past. Stanford University Press.

Jawitz, J. (2016). Unearthing white academics' experience of teaching in higher education in South Africa. Teaching in Higher Education, 21(8), 948-961.

Jenkins, R. (2008). Social identity (3rd ed.). New York.

LaBoskey, V. K. (2004). The methodology of self-study and its theoretical underpinnings. In J. J. Loughran, M. Hamilton, V. K. LaBoskey, \& T. L. Russell (Eds.), International handbook of self-study of teaching and teacher education practices (pp. 817-869). Kluwer.

Leggo, C. (2005). The heart of pedagogy: On poetic knowing and living. Teachers and Teaching, 11(5), 439-455.

Leggo, C. (2008). Astonishing silence: Knowing in poetry. In J. G. Knowles \& A. L. Cole (Eds.), Handbook of the arts in qualitative social science research (pp. 165-174). SAGE. 
Letseka, M., \& Maile, S. (2008). High university drop-out rates: A threat to South Africa's future. HSRC. http://www.hsrc.ac.za/uploads/pageContent/3330/2008marDropout\%20rates.pdf.

McIntosh, P. (1990). White privilege: Unpacking the invisible knapsack. Independent School, 49(2), 31-36.

Mngomezulu, S., \& Ramrathan, L. (2015). Academic intervention experiences of "at-risk" students in a South African university. Alternation: Interdisciplinary Journal for the Study of the Arts and Humanities in Southern Africa, Special Edition(17), 116-141.

Nussbaum, M. C. (1997). Cultivating humanity. Harvard University Press.

Percer, L. H. (2002). Going beyond the demonstrable range in educational scholarship: Exploring the intersections of poetry and research. The Qualitative Report, 7(2), 1-13.

Pillay, D., Naicker, S., \& Rawlinson, W. (2019). "To seek out something more": Knowing teacher-researcher self differently through found photos and self-narrative writing. In K. Pithouse-Morgan, D. Pillay, \& C. Mitchell (Eds.), Memory mosaics: Artful professional learning research. (pp. 15-34). Springer.

Pinnegar, S. (1998). Introduction to Part 11: Methodological perspectives. In M. L. Hamilton (Ed.), Reconceptualizing teaching practice: Self-study in teacher education (pp. 3133). Falmer Press.

Pithouse, K., Mitchell, C., \& Weber, S. (2009). Self-study in teaching and teacher development: A call to action. Educational Action Research, 17(1), 43-62.

Pithouse-Morgan, K., Naicker, I., Chikoko, V., Pillay, D., Morojele, P., \& Hlao, T. (2014). Entering an ambiguous space: Evoking polyvocality in educational research through collective poetic inquiry. Perspectives in Education, 32(4), 149-170.

Poindexter, C. C. (1998). Poetry as data analysis: Honoring the words of research participants. Reflections: Narratives of Professional Helping, 4(3), 22-25.

Posel, D. (2001). Race as common sense: Racial classification in twentieth-century South Africa. African Studies Review, 44(2), 87-114.

Prendergast, M. (2004). "Shaped like a question mark": Found poetry from Herbert Blau's The Audience. Research in Drama Education, 9(1), 73-92.

Prendergast, M. (2006). Found poetry as literature review: Research poems on audience and performance. Qualitative Inquiry, 12(2), 369-388. 
Prendergast, M. (2009). Introduction: The phenomena of poetry in research "poem is what?" Poetic inquiry in qualitative social science research. In M. Prendergast, C. Leggo, \& P. Sameshima (Eds.), Poetic inquiry: Vibrant voices in the social sciences (pp. XIXXLI). Sense.

Rawlinson, W. (2019). Exploring my communication pedagogy in diverse undergraduate classes at a university of technology: A self-study of practice [Unpublished doctoral dissertation]. University of KwaZulu-Natal, South Africa.

Richardson L. (1993). Poetics, dramatics, and transgressive validity: The case of the skipped line. Sociological Quarterly 34(4), 695-710.

Richardson, L. (1994. Writing: A method of inquiry. In N. Denzin \& Y. Lincoln (Eds.), Handbook of qualitative research (pp. 1410-1444). SAGE.

Sachs, J. (2001). Teacher professional identity: Competing discourses, competing outcomes. Journal of Education Policy, 16(2), 149-161.

Samaras, A. P. (2011). Self-study teacher research: Improving your practice through collaborative inquiry. SAGE.

Samaras, A. P., Hicks, M. A., \& Berger, J. G. (2004). Self-study through personal history. In J. J. Loughran, M. Hamilton, V. K. LaBoskey, \& T. L. Russell (Eds.), International handbook of self-study of teaching and teacher education practices (pp. 905-942). Kluwer.

Steyn, M. E. (2001). Whiteness just isn't what it used to be: White identity in a changing South Africa. Suny Press.

Straker, G. (2013). Unsettling whiteness. In G. Stevens, N. Duncan, \& D. Hook (Eds.), Race, memory and the apartheid archive: Towards a transformative psychosocial praxis (pp. 194-211). Springer.

Vale, P., \& Jacklin, H. (2009). Framing and revisiting: Debates old and new. In H. Jacklin \& P. Vale (Eds.), Re-imagining the social in South Africa: Critique, theory and postapartheid society (pp. 1-27). University of KwaZulu-Natal Press.

Walker, M. (2005). Race is nowhere and race is everywhere: Narratives from black and white South African university students in post-apartheid South Africa. British Journal of Sociology of Education, 26(1), 41-54.

Warren, J. T., \& Fassett, D. L. (2014). Communication: A critical/cultural introduction. SAGE.

Weber, S., \& Mitchell, C. (2004). Not just any dress: Narratives of memory, body, and identity. Peter Lang. 
West, M. (2009). White women writing white: Identity and representation in (post-) apartheid literatures in South Africa. David Philip.

Willis, P. (2002). Don't call it poetry. Indo-Pacific Journal of Phenomenology, 2(1). https://www.ajol.info/index.php/ipjp/article/view/65661 